\title{
Pengaruh Aromaterapi Lemon (Citrus) terhadap Skala Nyeri Dismenorea pada Mahasiswi Program Studi Ilmu Keperawatan STIKes Baiturrahim Jambi
}

\author{
Vita Febriyanti ${ }^{1}$, Vevi Suryenti Putri ${ }^{2}$, Rahmi Dwi Yanti ${ }^{3}$ \\ ${ }^{1-3}$ Prodi S1 Keperawatan STIKes Baiturrahim Jambi \\ Email:vitasasu@gmail.com
}

Submitted : 25/08/2020

Accepted: 12/02/2021

Published: 06 /03/2021

\begin{abstract}
Dysmenorrhea is a complaint that is often experienced by women during menstruation. Pain management can be done with complementary measures, one of which is by giving lemon aromatherapy (citrus). Lemon aromatherapy contains limonene which can inhibit prostaglandins thereby reducing pain. The purpose of this study was to determine the influence of Lemon Aromatherapy (Citrus) on dysmenorrhea pain scales at students nurse study program the college health science BaiturrahimJambi.This study was conducted by pre-experimental method with a one-group-pre-test-post-test design conducted at the respondent's home. The respondents were 20 females students who experienced dysmenorrhea. This study was conducted on June - July 2020. This study its mean before administration was 4.45 and after administration the mean was 3.25. Based on the results of statistical analysis using the Paired t test, the p-value was 0,000 ( $p<0.05)$.It can be concluded that there is an influence of lemon aromatherapy (citrus) on dysmenorrhea pain scales at students nurse study program the college health science Baiturrahim Jambi.
\end{abstract}

Keywords: dysmenorrhea, lemon aromatherapy (citrus), menstruation.

\begin{abstract}
Abstrak
Dismenorea merupakan keluhan yang sering dialami perempuan pada saat menstruasi.Penatalaksanaan nyeri dapat dilakukan dengan tindakan komplementer, salah satunya dengan pemberian aromaterapi lemon (citrus).Aromaterapi lemon mengandung limonene yang dapat menghambat prostaglandin sehingga mengurangi rasa nyeri.Tujuan penelitian ini adalah mengetahui pengaruh Aromaterapi Lemon (Citrus) Terhadap Skala Nyeri Menstruasi Pada Mahasiswi Program Studi Ilmu Keperawatan STIKes Baiturrahim Jambi.Penelitian ini menggunakan metode pre experiment dengan rancangan one-group-pre-test-post-test yang dilaksanakan di rumah responden.Jumlah responden sebanyak 20 mahasiswi yang mengalami dismenorea.Penelitian ini dilakukan pada bulan Juni-Juli 2020.Pada penelitian rata-rata mean sebelum pemberian 4.45 dan sesudah pemberian mean menjadi 3.25. Berdasarkan dari hasil analisa statistik menggunakan uji Paired $t$ Test didapatkan p-value $0.000(p<0.05)$.Pada penelitian ini dapat disimpulkan ada pengaruh aromaterapi lemon (citrus) terhadap skala nyeri dismenorea pada mahasiswi Program Studi Ilmu Keperawatan STIKes Baiturrahim Jambi.
\end{abstract}

Kata Kunci: aroma terapi lemon (citrus), dismenorea, menstruasi. 


\section{PENDAHULUAN}

Remaja adalah masa transisi antara masa anak dan dewasa, dimana terjadi pacu tumbuh (growth spurt), timbul ciri-ciri seks sekunder, tercapai fertilitas dan terjadi perubahan-perubahan psiklogik serta kognitif (Rohan \& Siyoto, 2013).

Masa remaja merupakan suatu proses transisi dari masa anak-anak menuju tahap dewasa yang ditandai dengan berubahnya perkembangan tubuh yang cepat. Masa remaja berhubungan dengan suatu fenomena fisik yang berhubungan dengan pubertas. Dimana pubertas merupakan suatu bagian penting dari masa remaja yang lebih menekankan proses biologis yang mengarah pada kemampuan reproduksi. Pada periode ini perempuan akan mengalami ovulasi dan menstruasi yang terkadang juga disertai nyeri haid (dysmenorrhea). Kondisi ini dapat bertambah parah bila disertai dengan kondisi psikis yang tidak stabil, seperti stres, depresi, cemas berlebihan, dan keadaan sedih atau gembira yang berlebihan (Anurogo \& Wulandari, 2011).

Menurut World Health Organization (WHO) tahun 2014 diperkirakan kelompok remaja berjumlah 1,2 milyar atau $18 \%$ dari jumlah penduduk dunia. Sedangkan menurut hasil Susenas tahun 2018 jumlah presentase penduduk di Indonesia berdasarkan kelompok umur 10-14 tahun 8,6\%, umur 15-19 tahun 8,2\% dan 20-24 tahun 8,0\% (Badan Pusat Statistik, 2018). Provinsi Jambi jumlah penduduk perempuan berdasarkan kelompok umur 1014 tahun 149.976 jiwa, 15-19 tahun 152.281 jiwa dan umur 20-24 tahun 151.674 jiwa (BKKBN, 2018).

Menstruasi merupakan peristiwa pengeluaran darah, mukus, dan sel-sel epitel dari uterus secara periodik.Menstruasi umumnya terjadi dengan interval setiap bulan selama periode reproduksi, kecuali selama kehamilan dan menyusui, peristiwa ini biasanya tersupresi (Reeder, 2012).Menstruasi (Haid) ialah perdarahan yang siklik dari uterus.Panjang siklus menstruasi ialah jarak antara tanggal mulainya perdarahan dinamakan hari pertama siklus. Panjang siklus menstruasi yang normal dianggap sebagai siklus yang klasik ialah 28 hari, tetapi variasinya cukup luas, bukan saja antara beberapa wanita mempunyai siklus menstruasi antara 24 sampai 35 hari (Fitri, 2017). Perubahan yang biasa dihadapi perempuan saat mengalami mestruasi yaitu cemas, stress, depresi dan biasanya di dampingi dengan gejala kejang-kejang menstruasi atau bahasa medisnya dysmenorrhea (Sukarni \& Wahyu, 2013).

Dismenorea adalah rasa sakit atau nyeri hebat pada bagian bawah perut, tetapi dapat menyebar hingga ke punggung bagian bawah, pinggang, panggul, paha atas hingga betis yang terjadi saat perempuan mengalami siklus menstruasi.Nyeri biasanya berlangsung sesaat sebelum menstruasi, selama menstruasi, hingga berakhirnya siklus menstruasi.Nyeri yang terus menerus membuat penderitanya tidak bisa beraktivitas (Ratnawati, 2018. Sinaga, dkk., 2017).

Nyeri merupakan pengalaman sensorik dan emosional yang tidak menyenangkan akibat kerusakan jaringan, baik aktual maupun potensial, atau yang digambarkan dalam bentuk kerusakan tersebut (Wiarto, 2017).

Nyeri menstruasi muncul akibat kontraksi disritmik miometrium yang menampilkan satu gejala atau lebih, mulai dari nyeri yang ringan sampai berat di perut bagian bawah, bokong, dan nyeri spasmodik disisi medial paha (Anurogo \& Wulandari, 2011).Pengukuran skala nyeri dapat dilakukan salah satunya dengan menggunakan Numerical Rating Scale (NRS), berat ringannya rasa sakit atau nyeri dibuat menjadi terukur dengan mengobyektifkan pendapat subyektif nyeri melalui pengukuran tersebut. Dengan keterangan nilai $0=$ tidak nyeri, nilai $1-3=$ nyeri ringan, nilai 4-6 = nyeri sedang, nilai 
7-9 $=$ nyeri berat, nilai $=10$ nyeri sangat berat (Wiarto, 2017).

Di Amerika Serikat, prevalesnsi dismenorea diperkirakan 45\%-90\%. Tingginya angka tersebut diasumsikan dari berbagai gejala yang belum dilaporkan.Bayak perempuan yang membeli obat sendiri dan tidak berkunjung ke dokter.Efek dari dismenorea menyebabkan ketidakhadiran saat bekerja dan sekolah, sebanyak $13 \%-51 \%$ perempuan telah absen sedikitnya sekali, 5\%-14\% berulang kali absen (Anurogo \& Wulandari, 2011).

Kondisi di Indonesia, lebih banyak perempuan yang mengalami dismenorea tidak melaporkan atau berkunjug ke dokter. Rasa malu ke dokter dan kecendrungan untuk meremehkan penyakit sering membuat data penderita penyakit tertentu di Indonesia tidak dapat dipastikan secara mutlak.Boleh dikatakan $90 \%$ perempuan Indonesia pernah mengalami dismenorea (Anurogo \& Wulandari, 2011). Penelitian United Nations Children's Fund (UNICEF) di Indonesia tahun 2015 menemukan fakta 1 dari 6 anak perempuan terpaksa tidak masuk sekolah selama satu hari atau lebih, pada saat menstruasi (Kemenkes, 2017).

Hasil penelitian dari Sari tahun 2019 dengan judul Gambaran Derajat Dismenorea (Nyeri Menstruasi) Dan Upaya Penanganan Pada Remaja Putri Usia 13-15 Tahun di SMPN 2 Tembilahan Ulu didapatkan responden yang mengalami Dismenorea derajat nyeri ringan sebanyak 41 orang $(50,6 \%)$, nyeri sedang 33 orang $(40,7 \%)$, dan nyeri berat $(8,7 \%)$.

Penatalaksanaan nyeri merupakan tujuan utama penyedia layanan kesehatan primer dan staf keperawatan.Sejumlah intervensi digunakan dalam penatalaksanaan nyeri baik berupa farmakologi seperti obat anti-inflamasi nonsteroid (nonsteroidal anti-inflammatory drugs, NSAID).Pemberian obat dan penyedia pelayanan kesehatan primer dapat memprogramkan intervensi alternatif dan komplementer yang disediakan oleh individu yang terlatih secara khusus.Tindakan alternatif dan komplementer seperti perawatan chiropractic, akupuntur, akupresur, hiposis, homeopati, penggunaan esens bungadan minyak aromatik serta pengobatan herbal (Rosdahl \& Kowalski, 2014).

Aromaterapi adalah pengobatan komplementer yang menggunakan bahan berbentuk cairan yang terbuat dari tanaman dan mudah menguap, dikenal sebagai minyak esensial dan senyawa aromatik lainnya yang dapat mempengaruhi jiwa, emosi, fungsi kognitif dan kesehatan seseorang (Putri \& Amalia, 2019).Aromaterapi masuk kedalam pengobatan naturopati yang merupakan sistem pengobatan alami dengan pendekatan holitik, menggunakan keseimbangan energi dari tubuh, mngutamakan pengobatan yang terbuat bahan alami (mengesampingkan obatobatan buatan manusia) serta meminimalisir pembedahan.Beberapa jenis aromaterapi yang popular seperti aromaterapi tea tree, melati, lavender, pappermint, ylang-ylang dan lemon (Putri \& Amalia, 2019).

Lemon mengandung 2,5\% minyak atsiri, vitamin $\mathrm{C}$, hesperidin dan glikosida flavanon, musilago dan kalsium oksalat (Sukadirman, 2020). Lemon (citrus) essential oil(EO)dikenal sebagai penghilang stres alami. Menghirup lemon essential oil (EO) menyebabkan efek anti-stres dengan memodulasi aktivitas serotonin (5-HT) dan dopamin (DA) (Ramadan, 2019).Dan juga aromaterapi dari lemon (citrus) berfungsi sebagai pembersih dan tonik, penurun panas, meningkatkan sistem imun pada kondisi tubuh yang demam, anti oksidan, antiseptic, mencegah hipertensi, serta mengurangi emosi yang berlebihan (Putri \& Amalia, 2019).Dalam aromaterapi minyak esensial lemon memiliki berbagai macam kegunaan, salah satunya lemon memberikan rasa hangat dan dan bermanfaat bagi secara fisik dan psikologis (Najib, 2012). 


\section{METODE PENELITIAN}

Penelitian ini menggunakan desain penelitian Pre-Eksperiment dengan rancangan one-group-pre-test-posttest.Penelitian ini dilaksanakan pada bulan Juni-Juli 2020 disesuaikan dengan protokol kesehatan new normal.Tekhnik pengambilan sampel dalam penelitian ini menggunakan tekhnik purposive sampling. Sampel dalam penelitian ini berjumlah 20 responden yang telah memenuhi kriteria inklusi: Mahasiswi PSIK yang masih aktif kuliah, Mahasiswi yang bersedia menjadi responden, Mahasiswi yang tidak memiliki alergi terhadap minyak aromaterapi lemon, Mahasiswi yang sedang menstruasi, Mahasiswi yang sedang dismenorea dengan skala nyeri 4-6 (sedang). Instrument dalam penelitian ini menggunakan observasi nyeri dengan Numerik Rating Scale (NRS). Analisa data menggunakan uji Paired $t$ Test.

Bahan dalam penatalaksanaan penelitian ini ialah berupa minyak aromaterapi lemon (citrus) yang diteteskan kedalam mangkuk kecil berisi air hangat dan kapas, lalu dihirup selama kurang lebih 5 sampai 10 menit terhadap satu responden. Hal ini sesuai dalam buku karya Putri \& Amalia tahun 2019 yang berjudul Terapi Komplementer Konsep Dan Aplikasi Dalam Keperawatan, dimana ada 3 cara dalam menggunakan aromaterapi salah satunya dengan cara inhalasi langsung yaitu dengan menghirup uap minyak esensial seperti desinfektan dan dekongestan.

HASIL DAN PEMBAHASAN

Tabel 1 Distribusi Frekuensi Karakteristik Responden Berdasarkan Umur

\begin{tabular}{ccc}
\hline Umur & $\mathbf{N}$ & $\mathbf{\%}$ \\
\hline 18 Tahun & 1 & 5 \\
19 Tahun & 3 & 15 \\
20 Tahun & 9 & 45 \\
21 Tahun & 7 & 35 \\
\hline total & 20 & 100 \\
\hline
\end{tabular}

Berdasarkan Tabel 1 diketahui bahwa dari 20 responden sebanyak 1 (5\%) berusia 18 tahun, sebanyak $3(15 \%)$ berusia 19 tahun, sebanyak $9(45 \%)$ berusia 20 tahun dan sebanyak $7(35 \%)$ berusia 21 tahun.

Hasil penelitian ini sejalan dengan penelitian yang dilakukan oleh Sono (2019), dengan hasil yang didapatkan rentang usia responden adalah 17-22 tahun yang dikategorikan menjadi remaja dan dewasa. Sesuai dengan hasil pengukuran bahwa responden terbanyak yang didapatkan memiliki usia 20 tahun atau 26,9\%.Menurut Patimah (2016) remaja dikelompokkan ke dalam 3 tahap perkembangan, dalam 3 tahap perkembangan ini remaja akhir (18-21).

\section{Tabel 2 Distribusi Frekuensi Berdasarkan Pernah atau Tidak} Mengalami Dismenorea Sebelumnya

\begin{tabular}{lcc}
\hline $\begin{array}{c}\text { Pengalaman } \\
\text { Dismenorea }\end{array}$ & Frekuensi & Presentasi \% \\
\hline Ada & 20 & 100 \\
Jumlah & 20 & 100 \\
\hline
\end{tabular}

Berdasarkan tabel 2 diketahui bahwa dari 20 responden sebanyak $20(100 \%)$ ada pengalaman dismenorea.

Hasil penelitian ini sejalan dengan penelitian yang dilakukan oleh Nisak (2017), dengan hasil penelitian menunjukkan bahwa dari beberapa karakteristik remaja putri yaitu umur, usia menarche, lama menstruasi dan riwayat dismenorea keluarga, didapatkan hasil bahwa terdapat korelasi yang bermakna antara riwayat dismenorea keluarga dengan respon nyeri dismenorea dengan $p$ velue $=0,000$, nilai $r=-0,482$, ini dapat diartikan bahwa remaja putri dengan riwayat keluarga yang juga mengalami dismenorea memiliki kekuatan hubungan yang sedang dengan respon nyeri dismenorea dan mempunyai arah korelasi negative. Peluang mengalami nyeri dismenorea lebih berat akan semakin tinggi pada remaja putri dengan riwayat 
dismenorea keluarga. Nyeri yang dirasakan sebagian responden dapat disebabkan karena beberapa faktor diantaranya pengalaman nyeri sebelumnya, usia, ansietas, dan makna nyeri (Judha, 2012).

Tabel 3 Distribusi Skala Nyeri Disminore Sebelum dan Sesudah Pemberian Aromaterapi Lemon (Citrus)

\begin{tabular}{cccc}
\hline No. & $\begin{array}{c}\text { Nilai } \\
\text { Pre }\end{array}$ & $\begin{array}{c}\text { Nilai } \\
\text { Post }\end{array}$ & Selisih \\
\hline 1 & 4 & 3 & 1 \\
2 & 5 & 4 & 1 \\
3 & 4 & 2 & 2 \\
4 & 4 & 3 & 1 \\
5 & 5 & 4 & 1 \\
6 & 5 & 4 & 1 \\
7 & 4 & 3 & 1 \\
8 & 5 & 4 & 1 \\
9 & 4 & 3 & 1 \\
10 & 5 & 4 & 1 \\
11 & 4 & 3 & 1 \\
12 & 5 & 4 & 1 \\
13 & 4 & 3 & 1 \\
14 & 5 & 3 & 2 \\
15 & 4 & 2 & 2 \\
16 & 5 & 4 & 1 \\
17 & 4 & 2 & 2 \\
18 & 4 & 3 & 1 \\
19 & 5 & 4 & 1 \\
20 & 4 & 3 & 1 \\
\hline
\end{tabular}

Berdasarkan tabel 3diketahui bahwa mayoritas selisih skala nyeri disminore pada mahasiswi Program Studi Ilmu Keperawatan sebelum dan sesudah dilakukan aromaterapi lemon (citrus) di STIKes Baiturrahim Jambi adalah 1-2.

Tabel 4 Skala Nyeri Disminore Sebelum dan Sesudah Pemberian Aromaterapi Lemon (Citrus)

\begin{tabular}{lllll}
\hline $\begin{array}{l}\text { Skala } \\
\text { Nyeri }\end{array}$ & Mean & SD & $\begin{array}{l}\text { Min- } \\
\text { Maks }\end{array}$ & $\begin{array}{l}\text { 95\% } \\
\text { CI }\end{array}$ \\
\hline Sebelum & 4,45 & 0,510 & $4-5$ & $4,21-$ \\
& & & & 4,69 \\
Sesudah & 3,25 & 0,716 & $2-4$ & $2,91-$ \\
& & & & 3,59 \\
\hline
\end{tabular}

Berdasarkan tabel 4 diketahui bahwa nilai rata skala nyeri disminore sebelum mendapatkan aromaterapi lemon (citrus) adalah 4,45 dengan standar devisiasi 0,510. Nilai terendah skala nyeri disminore sebelum medapatkan aromaterapi lemon (citrus) 4 dan nilai tertinggi adalah 5. Dari hasil estimasi interval dapat disimpulkan bahwa 95\% diyakini bahwa rata - rata skala nyeri disminore sebelum medapatkan aromaterapi lemon (citrus) adalah diantara 4,21 sampai dengan 4,69.

Nilai rata skala nyeri disminore sesudah mendapatkan aromaterapi lemon (citrus) adalah 3,25 dengan standar devisiasi 0,716 . Nilai terendah skala nyeri disminore sesudah medapatkan aromaterapi lemon (citrus) 2 dan nilai tertinggi adalah 4 . Dari hasil estimasi interval dapat disimpulkan bahwa 95\% diyakini bahwa rata - rata skala nyeri disminore sesudah medapatkan aromaterapi lemon (citrus) adalah diantara 2,91 sampai dengan 3,59.

Hasil penelitian ini sejalan dengan penelitian yang dilakukan Suwanti (2018), dengan judul pengaruh aromaterapi lemon (citrus) terhadap penurunan nyeri menstruasi sebelum diberikan aromaterapi lemon adalah mean 4,95, median 5 standar deviasi 1,146 dengan skala nyeri rendah 2 dan tertinggi 6 . Nyeri menstruasi muncul akibat kontraksi disritmik miometrium yang menampilkan satu gejala atau lebih, mulai dari nyeri yang ringan sampai berat di perut bagian bawah, bokong, dan nyeri spasmodik disisi medial paha (Anurogo \& Wulandari, 2011).

Penelitian oleh Rahmawati (2015), bahwa hasil intensitas nyeri sebelum diberikan aromaterapi lemon dapat diketahui bahwa tingkat nyeri haid dari 17 remaja putri sebelum dilakukan teknik aromaterapi sebagian remaja putri yang mengalami nyeri haid tingkat sedang sebanyak 8 remaja putri $(47.1 \%), 6$ sedangkan yang mengalami nyeri ringan 
sebanyak 5 remaja putri (29.4\%), sedangkan yang mengalami nyeri berat terkontrol sebanyak 4 remaja putri $(23.5 \%)$. Dari hasil pengukuran pre-test sebelum diberikan aromaterapi, sebagian besar mengalami nyeri sedang.

Tabel 5 Aromaterapi Lemon (Citrus) Terhadap Skala Nyeri Dismenorea

\begin{tabular}{lccccc}
\hline $\begin{array}{l}\text { Skala } \\
\text { Nyeri }\end{array}$ & $\begin{array}{c}\text { Mea } \\
\text { n }\end{array}$ & SD & SE & $\begin{array}{c}\text { P } \\
\text { Va } \\
\text { lue }\end{array}$ & N \\
\hline $\begin{array}{lcccc}\text { Sebel } \\
\text { um }\end{array}$ & 4,45 & 0,51 & 0,11 & & \\
$\begin{array}{l}\text { Sesud } \\
\text { ah }\end{array}$ & 3,25 & 0,71 & 0,16 & 00 & 0 \\
& & 6 & 0 & & \\
\hline
\end{tabular}

Berdasarkan tabel 5 diketahui bahwa nilai rata-rata mahasiswi Program Studi Ilmu Keperawatan STIKes Baiturrahim Jambi tentang skala nyeri disminore sebelum mendapatkan aromaterapi lemon (citrus) adalah 4,45 dengan standar devisiasi 0,510. Nilai Standar eror mean adalah 0,114. Nilai rata mahasiswi Program Studi Ilmu Keperawatan STIKes Baiturrahim Jambi tentang skala nyeri disminore sesudah mendapatkan aromaterapi lemon (citrus) adalah 3,25 dengan standar devisiasi 0,716. Nilai Standar eror mean adalah 0,160 . Hasil uji statistik didapatkan nilai 0,000 maka dapat disimpulkan ada pengaruh aromaterapi lemon (citrus) terhadap skala nyeri dismenorea pada mahasiswi Program Studi Ilmu Keperawatan STIKes Baiturrahim Jambi.

Hasil penelitian ini didukung oleh penelitian yang dilakukan Suwanti (2018) analisis aromaterapi lemon (cytrus) terhadap penurunan nyeri menstruasi menunjukan bahwa intensitas nyeri sebelum diberikan aromaterapi lemon (citrus) adalah mean 4,95 dengan standar deviasi 1,146. Intensitas nyeri menstruasi sesudah diberikan aromaterapi lemon (citrus) nilai mean menjadi 2, 65 dan standar deviasi 1,040.Terlihat perbedaan nilai median sebelum dan sesudah adalah 2, 3. Hasil uji statistik menggunakan uji Wilcoxon nilai P-value sig.(2-tailed) sebesar 0,000 yang artinya kurang dari nilai $\alpha(0,05)$.

Berdasarkan tabel 4.6 skala nyeri dismenorea sesudah diberikan aromaterapi lemon (citrus) yaitu nilai mean 3,25, standar deviasi 0,716 , dengan skala nyeri terendah 2 dan tertinggi 4. Nyeri yang dirasakan sebagian responden dapat disebabkan karena beberapa faktor diantaranya adalah pengalaman nyeri sebelumnya, usia, ansietas, keletihan dan makna nyeri (Judha, 2012). Nyeri menstruasi dapat terjadi bervariasi mulai dari yang ringan sampai berat dapat dirasakan di perut bagian bawah atau pinggang dapat bersifat seperti mules-mules seperti ngilu, atau ditusuk-tusuk (Prawirohadjo, 2011).

Hasil penelitian ini didukung oleh penelitian yang dilakukan Sono (2019) bahwa nyeri menstruasi setelah diberikan aromaterapi lemon (citrus) yaitu nilai mean 2,82, standar deviasi 0,796, dengan skala nyeri 1-3 (ringan), terdapat pengaruh yang signifikan antara aromaterapi lemon terhadap penurunan nyeri menstruasi sebelum dan sesudah diberikan aromaterapi lemon (citrus) yaitu $\mathrm{P}=0,000$ yang lebih kecil dari $\alpha=0,05$. Yang mana terdapat pengaruh aromaterapi lemon (Citrus) terhadap penurunan nyeri menstruasi pada mahasiswi Ilmu Keperawatan Fakultas Kedokteran Universitas Sam Ratulangi Manado.

Penelitian lain yang mendukung yaitu penelitian Listiani (2018) setelah pemberian aromaterapi lemon (citrus) pada mahasiswi S1 Ilmu Keperawatan Universitas Muhammadiyah Semarang didapatkan nilai mean 3,06, standar deviasi 0,928, dengan skala nyeri 2-5 (ringan-sedang). Terdapat efektifitas tingkat nyeri yang signifikan antara kelompok yang diberikan aromaterapi lemon dengan kelompok yang 
tidak diberikan aromaterapi lemon dengan $\mathrm{p}$ value $0,000<\alpha 0,05$.

Hasil penelitian dilapangan, setelah responden mengisi lembar observasi pada google form dilanjutkan dengan penelitian menggunakan aromaterapi lemon (citrus).Responden mengatakan sebelumnya nyeri yang dirasa seperti ditekan dan ditusuk-tusuk, mood pada responden juga gampang berubah.Dan beberapa responden mengatakan tidak nyaman dengan rasa nyeri dismenorea yang dirasa pada saat beraktivitas.Hasil dari observasi responden menyukai aromaterapi lemon (citrus), dan pada saat menghirup aromaterapi lemon (citrus) responden merasa rileks.Setelah istirahat selama kurang lebih 30 menit dan dilanjutkan dengan menghirup aromaterapi yang kedua kalinya responden semakin rileks dan memberikan dampak positif berupa penurunan skala nyeri dismenorea yang dirasakan pada saat itu.Hal ini dapat disebabkan karena wangi yang dihasilkan oleh aromaterapi lemon akan menstimulasi thalamus untuk mengaktifkan pengeluaran neurotransmitter yang berfungsi sebagai penghilang rasa sakit alami, enchephalines merupakan neuromodulator yang berfungsi menghambat nyeri fisiologi (Solehati, dkk., 2015).

Aromaterapi lemon mengandung limeone, limeone adalah komponen utama dalam senyawa kimia jeruk yang dapat menghambat sistem kerja prostaglandin sehingga dapat mengurai nyeri. Selain itu limeone akan mengontrol siklogienase I dan II, mencegah aktivitas prostaglandin dan mengurangi rasa sakit. Aromaterapi ini bermanfaat untuk mengurangi ketegangan otot yang akan menurangi tingat nyeri. Sebagian besar obat penghilang rasa sakit dan obat antiinflamasi mengurangi rasa sakit dan peradangan dengan mengendalikan enzim ini. Bisa disimpulkan bahwa limeono dalam lemon (citrus) akan mengontrol prstagladin dan mengurani rasa nyeri (Namazi, dkk. 2014).
Essential oil (EO) pada buah lemon dikenal sebagai penghilang stres alami.Menghirup essential oil (EO) lemon dapat menyebabkan efek anti-stres dengan memodulasi aktivitas serotonin (5-HT) dan dopamin (DA).Sehingga berpengaruh langsung pada organ penciuman dan dipersepsikan oleh otak untuk memberikan reaksi yang membuat perubahan fisiologis pada tubuh, pikiran, jiwa, dan menghasilkan efek menenangkan pada tubuh (Ramadan, 2019).

Dilihat dari segi biaya dan manfaat penggunaan terapi komplementer khususnya dealam konsep naturopati, dalam hal ini menggunakan aromaterapi lemon (citrus) dianggap ekonomis dan tidak ada efek sampingnya karena pengobatan alami yang bersifat holistik. Dibandingkan dengan menejemen farmakologis yang memiliki efek samping apabila di konsumsi dalam jangka panjang akan menimbulkan ketergantungan (Putri dan Amalia, 2019).

\section{SIMPULAN}

Berdasarkan hasil penelitian dan pembahasan tentang pengaruh aromaterapi lemon (citrus) terhadap skala nyeri dismenorea pada mahasiswi Program Studi Ilmu Keperawatan STIKes Baiturrahim Jambi, maka dapat disimpulkan sebagai berikut :Skala nyeri dismenorea sebelum pemberian aromaterapi lemon (citrus) 4-5 (skala sedang) dengan mean 4,45, standar deviasi 0,510. Skala nyeri dismenorea sesudah pemberian aromaterapi lemon (citrus) 2-4 (skala ringan - sedang) dengan mean 3,25, standar deviasi 0,716. adapengaruh aromaterapi lemon (citrus) terhadap skala nyeri dismenorea pada mahasiswi Program Studi Ilmu Keperawatan STIKes Baiturrahim Jambi dengan nilai $\mathrm{p}$ value $=0,000$.

\section{SARAN}

Diharapkan dapat melakukan penelitian tentang perbandingan tingkat skala nyeri dismenorea pada variabel yang 
berbeda, melibatkan lebih banyak responden dan waktu yang lebih lama dan pas sehingga penelitian dapat lebih akurat hasilnya.

\section{DAFTAR PUSTAKA}

Anurogo, D., \& Wulandari, A. (2011). Cara Jitu Mengatasi Nyeri Haid. Yogyakarta: Andi Offset

Badan Pusat Statistik. (2018). Penduduk Kota Jambi 2018. Jambi: Badan Pusat Statistik Kota Jambi

Fitri, I. (2017). Lebih Dekat Dengan Sistem Reproduksi Wanita. Yogyakarta: Gosyen Publishing

Judha, M., Sudarti \& Fauziah, A. (2012). Teori Pengukuran Nyeri \& Nyeri Persalinan Disertai Contoh Askep. Yogyakarta: Nuha Medika

Kemenkes RI. (2017). Manajemen Kebersihan Menstruasi Perlu Dipahami.

http://www.kemkes.go.id/article/view /17052700001/manajemen-

kebersihan-menstruasi-perludipahami-.html. Diakses 25 Februari 2020

Listiani, U. (2018).Efektifitas Aromaterapi Lemon Untuk Menurunkan Nyeri Menstruasi (Dismenore) Pada Mahasiswi Keperawatan Universitas Muhammadiyah Semarang. Skripsi. Prodi Ilmu Keperawatan Universitas Muhammadiyah Semarang. http://repository.unimus.ac.id diakses tanggal 16 Juli 2020

Najib, A. (2012). Obat Asli Indonesia. Universitas Muslim indonesia. id.scribd.com/doc/91093474/Citruslimon. Diakses 25 Februari 2020

Namazi, M., Akbari, A.S., Mojab, F., Talebi, A., Majd, H.A. \& Jannesari, S.(2014). Effect of Citrus Aurantium (Bitter Orange) on the Severity of First-Stage Labour Pain.Iranian Journal of Pharmaceutical Research

Nisak, A., Z., \& Azizah, N. (2017). Respon
Nyeri Dismenorea Berdesarkan Karakteristik Remaja Putri. Indonesia Jurnal Kebidanan, Vol 1 (2)

Patimah Sitti. (2016). GIZI REMAJA PUTRI PLUS 1000 HARI PERTAMA KEHIDUPAN. Bandung:Refika Aditama

Putri, D., M., P., \& Amalia, R., N. (2019). Terapi Komplementer Konsep Dan Aplikasi Dalam Keperawatan. Yogyakarta: Pustaka Baru

Prawirohadjo, S. (2011). Ilmu Kandungan Edisi 3. Jakarta: Bina Pustaka

Ramadan, M. F. 2019. Fruit Oils: Chemistry and Functionality. Switzerland: Spinger

Ratnawati, A. (2018). Asuhan Keperawatan Pada Pasien Dengan Gangguan Sistem Reproduksi. Yogyakarta: PUSTAKA BARU PRESS

Reeder, S. J., Martin, L. L., \& Griffin, K. D. (2012). Keperawatan Maternitas Kesehatan Wanita, Bayi \& Keluarga, Vol 1. Jakarta: EGC

Rosdahl, C. B., Kowalski, M. T. (2014). Buku Ajar Keperawatan Dasar, Edisi 10. Jakarta: EGC

Sinaga, E., dkk. (2017). Manajemen Kesehatan Menstruasi. Jakarta: IWWASH

Sari, M., R. (2019). Gambaran Derajat Dismenorea (Nyeri Haid) Dan Upaya Penanganan Pada Remaja Putri Usia 13-15 Tahun Di SMPN 2 Tembilahan Hulu. Jurnal Kesehatan Husada Gemilang, Vol 1 (1)

Sono, D., Rompas, S., \& Gannika, L. (2019). Pengaruh Aromaterapi Lemon (Cytrus) Terhadap Penurunan Nyeri Menstruasi Pada Mahasiswi Program Studi Ilmu Keperawatan Fakultas Kedokteran Universitas Sam Ratulangi Manado. Ejournal Keperawatan, Vol 7 (1)

Solehati, dkk. (2015). Konsep dan Aplikasi Relaksasi dalam Keperawatan Maternitas. Bandung: PT Refika Aditama 
$\begin{array}{rlr}\text { Sukardiman, dkk. } & 2020 . & \text { Buku Ajar } \\ \text { Farmakognosi } & \text { Jilid } & \text { 1. Surabaya: }\end{array}$ Airlangga University Press

Sukarni, K. \& Wahyu, P. (2013). Buku Ajar Keperawatan Maternitas. Yogyakarta: Nuha Medika

Suwanti, S., Wahyuningsih, M., \& Liliana, A. (2018). Pengaruh Aromaterapi Lemon (Cytrus) Terhadap Penurunan Nyeri Menstruasi Pada Mahasiswi di Universitas Respati Yogyakarta. Jurnal Keperawatan Respati Yogyakarta, Vol 5 (1), 345-349
Rahmawati, I. (2015). Efektivitas Aromaterapi Lavender Dan Aromaterapi Lemon Terhadap Intensitas Nyeri Post Sectio Caesarea (Sc) Di Rumah Sakit Budi Rahayu Kota Magelang. Journal Of Holistic Nursing Science, 2(2), 11- 17

Rohan, H. H., \& Siyoto, S. (2013). Buku Ajar Kesehatan Reproduksi. Yogyakarta: Nuha Medika

Wiarto, G. (2017). Nyeri Tulang dan Sendi. Yogyakarta: Gosyen Publishing 